\title{
УOBOЗНАВCTBO. ПUTEPATУРOЗНАВCTBO
}

\author{
УДК 811:378.4-057.4
}

DOI https://doi.org/10.24919/2308-4863/35-2-12

\author{
Маргарита ГОЛТВЕНИЦЬКА, \\ orcid.org/0000-0002-3130-271X \\ кандидат філологічних наук, \\ старший викладач кафедри іноземної і украӥнської філології \\ Харківської державної академії дизайну і мистеитв \\ (Харків, Україна) margarita_info@ukr.net
}

\section{КОМПЕТЕНТНІСНИЙ ПІДХІД У ВИКЛАДАННІ УКРАЇНСЬКОЇ МОВИ ЗА ПРОФЕСІЙНИМ СПРЯМУВАННЯМ ЗДОБУВАЧАМ ВИЩОЇ ОСВІТИ ТВОРЧИХ СПЕЦАЛЬНОСТЕЙ}

\begin{abstract}
Основне завдання сучасної вищої освіти - формування творчої особистості фахівия, який здатен самостійно розвиватися та адаптуватися в суспільстві, щуо забезпечить високий рівень його конкурентоспроможності на сучасному ринку праці. Саме такий орієнтир зумовлює актуальність застосування компетентнісного підходу в підготовці майбутніх фахівців. Однак попри значний науковий доробок у цій ияарині, дотепер детально не було викладено питання реалізаиії иьього підходу на заняттях з украӥнської мови за професійним спрямуванням, зокрема для здобувачів вищої освіти, які навчаються за творчими спеціальностями, щчо й підтверджує необхідність його розгляду.

Об'єктом дослідження є компетентнісний підхід у викладанні украӥнської мови за професійним спрямуванням. Безпосереднім предметом вивчення виступають зміст і форми розвитку мовної та мовленнєвої компетениій як невіддільних складників загальних і фахових програмних компетентностей здобувачів вищої освіти творчих спеціальностей.

Мета розвідки - проаналізувати можливості запровадження компетентнісного підходу під час викладання украӥнської мови за професійним спрямуванням здобувачам вищої освіти творчих спеціальностей.

Дослідниия уточнює дефінічії понять «компетентнісний підхід», «мовна компетенція», "мовленнєва компетенція»; розглядає форми роботи й різновиди завдань, які доиільно застосовувати на заняттях з украӥнської мови за професійним спрямуванням для формування мовної та мовленнєвої компетенцій як складників відповідних фахових $і$ загальних компетентностей здобувачів вищої освіти.

Автор доходить висновку, щуо застосування компетентнісного підходу уможливлює узгодження мети навчання, визначеної педагогами, з метою самих студентів. У зв'язку із иим головним учасником освітнього процесу стає саме студент, який розвиває особистісний потенціал, завдяки чому підвищується рівень мотивованості для самостійного досягнення поставленої мети, розвивається уміння самостійно приймати важливі рішення.

Ключові слова: компетентнісний підхід, мовна компетенція, мовленнєва компетенція, українська мова за професійним спрямуванням.
\end{abstract}

Margarita GOLTVENYTSKA, orcid.org/0000-0002-3130-271X Candidate of Philological Sciences,

SeniorLecturer at the Department of Foreign and Ukrainian Philology Kharkiv State Academy of Design and Arts (Kharkiv, Ukraine) margarita_info@ukr.net

\section{COMPETENCE APPROACH IN TEACHING THE UKRAINIAN FOR SPECIFIC PURPOSE TO RECIPIENTS OF HIGHER EDUCATION OF CREATIVE SPECIALTIES}

The main task of modern higher education is to train a creative specialist who is able to develop and adapt in society independently which will ensure a high level of its competitiveness in the modern labour market. This aim determines the relevance of the application of the competency approach in the training of future professionals. Despite the significant scientific achievements in this area the issue of implementing this approach in Ukrainian language classes in professional fields, in particular for higher education students studying in creative specialties has not been covered in detail so far and it confirms the necessity to consider it. 
The object of the research is the competence approach in teaching Ukrainian for specific purpose. The direct subject of study is the content and forms of language and speech competencies development as integral components of general and professional program competencies of graduates in creative specialties.

The purpose of the research is to analyze the possibilities of introducing a competency-based approach in the teaching of Ukrainian for specific purpose to applicants for higher education in creative specialties.

The researcher has clarified the definitions of the concepts "competence approach", "language competence", "and "speech competence"; considered the forms of work and types of tasks that should be used in Ukrainian for specific purpose classes for the formation of language and speech competencies as components of the relevant professional and general competencies of higher education.

The author concludes that the application of the competency approach makes it possible to coordinate the purpose of learning which is defined by teachers with the goal of the students. In this case the main participant in the educational process is the student who develops personal potential which increases the level of motivation to achieve the goal, develops the ability to make important decisions.

Key words: competence approach, language competence, speech competence, Ukrainian language for special purposes.

Постановка проблеми. Формування творчої особистості фахівця, який здатен самостійно розвиватися та адаптуватися в суспільстві, що забезпечить високий рівень його конкурентоспроможності на сучасному ринку праці, - основне завдання сучасної вищої освіти. Саме такий орієнтир зумовлює актуальність застосування компетентнісного підходу в підготовці майбутніх фахівців.

Аналіз останніх досліджень. До проблеми застосування компетентнісного підходу в навчанні зверталися такі вітчизняні вчені, як В. Балух, Н. Бібік, В. Богомолова, І. Срмаков, О. Ісаєва, Л. Кожуховська, О. Овчарук, Г. Потапенко, О. Потапенко, Г. Сиротенко, Ю. Швалб та інші. Однак попри значний науковий доробок у цій царині, дотепер детально не було викладене питання реалізації компетентнісного підходу на заняттях 3 української мови за професійним спрямуванням, зокрема для здобувачів вищої освіти, що навчаються за творчими спеціальностями, що й підтверджує необхідність його розгляду, а отже й актуальність порушеної проблеми.

Об'єктом дослідження є компетентнісний підхід у викладанні української мови за професійним спрямуванням. Безпосереднім предметом вивчення виступають зміст і форми розвитку мовної та мовленнєвої компетенцій як невіддільних складників загальних і фахових програмних компетентностей здобувачів вищої освіти творчих спеціальностей.

Мета розвідки - проаналізувати можливості запровадження компетентнісного підходу під час викладання української мови за професійним спрямуванням здобувачам вищої освіти творчих спеціальностей. Для досягнення окресленої мети необхідно виконати такі завдання: уточнити визначення понять «компетентнісний підхід», «мовна компетенція», «мовленнєва компетенція»; розглянути форми роботи й різновиди завдань, які доцільно застосовувати на заняттях 3 української мови за професійним спрямуванням для формування мовної та мовленнєвої компетенцій як складників відповідних фахових і загальних компетентностей здобувачів вищої освіти.

Виклад основного матеріалу. У сучасній науковій літературі компетентнісний підхід до навчально-виховного процесу здебільшого трактують як «дієвий освітній інструмент розвитку особистості, спрямований на активне й конструктивне входження людини в сучасні суспільні процеси» (Срмаков, 2011: 21).

Компетентнісний підхід традиційно грунтується на двох основних поняттях: компетениія та компетентність, які співвідносяться як часткове й загальне. Компетенція - це сукупність знань, умінь, навичок, способів діяльності, необхідних для якісної продуктивної діяльності, а компетентність - індивідуальний практичний досвід успішного застосування тієї чи тієї компетенції. Оскільки компетентнісний підхід в освіті - це цільове орієнтування навчального процесу на формування відповідних компетенцій (Стёпина, 2009: 193), то в системі підготовки майбутніх фахівців доцільно виділити мовну й мовленнєву компетенції, що виступають складниками загальних і фахових програмних компетентностей.

Поняття мовна компетенція та мовленнєва компетенція дотепер визначають по-різному. Так, американський дослідник Н. Хомський, увівши в науковий обіг термін мовна компетенція, трактував іiі як «ідеальне знання мовця-слухача про свою мову», що складається з природженого знання лінгвістичних універсалій (категорій) і здатності «конструювати для себе граматику» (Хомский, 1972). Вітчизняні дослідники вказують на те, що мовна компетенція - це імплічитне знання (імпліцитна обізнаність), що уможливлює розуміння та творення мовцем кожного разу нових речень, які він може розрізняти як граматично 
правильні й неправильні, перефразовувати, витворюючи синонімічні конструкції, без зміни змісту висловлювання, розпізнавати багатозначність (Бібік, 2004: 227). Також вони розглядають мовну компетенцію як засвоєння, усвідомлення мовних норм, що склалися історично в фонетиці, лексиці, граматиці, орфоепії, семантиці, стилістиці, й адекватне їх застосування в професійній діяльності (Лопатинська, 2015). Науковці стверджують, що мовну компетенцію визначають знання учасниками спілкування мовних законів, правил, за якими формуються правильні мовні конструкції та повідомлення, здійснюється їх трансформація (Мамчур, 2006), а також зауважують, що мовна компетенція передбачає засвоєння студентом основ науки про мову, знання пii системи, володіння способами й навичками якісної діяльності 3 вивченим мовним матеріалом (Островська, Беганська, 2009). Отже, підгрунтям формування мовної компетенції є свідоме опанування знаннями про мову на всіх їі рівнях.

Але деякі дослідники тлумачать мовну компетенцію як загальне комплексне поняття, що свідчить про рівень навчальних досягнень із мови й мовленнєвого розвитку студента (Кордонська, 2018) або як психологічну систему, що містить мовний досвід, накопичений людиною в процесі спілкування, та знання про мову, засвоєні в процесі спеціально організованого навчання (Крутій, 2007), чи наголошують, що визначення мовної компетенції неможливе без урахування показників інтерференції, продуктивності мовлення, здатності утворювати нові форми, швидкості / легкості мовлення, його правильності, насиченості, семантичної та стилістичної відповідності (Шумарова, 2000). Однак такі підходи спричиняють плутанину, оскільки в останніх трьох визначеннях поняття мовний і мовленнєвий ототожнюються.

Єдиної універсальної дефініції терміна мовленнєва компетенція так само немає. Це поняття трактують і як знання правил вираження розумового змісту за допомогою певної мови й володіння необхідними для цього виду діяльності операційними структурами й навичками їх реалізації (Глазова; Заболоцька, 2003), і як уміння адекватно й доречно практично користуватися мовою в конкретних ситуаціях (висловлювати свої думки, бажання, наміри, прохання тощо), використовувати для цього як мовні, так і позамовні (міміка, жести, рухи) й інтонаційні засоби виразності мовлення (Бібік, 2004: 13), або здатність особистості використовувати мову для досягнення поставлених конкретною мовленнєвою ситуацією цілей, використовуючи для цього мовні, поза- мовні й інтонаційні засоби виразності відповідно до наявних у мові норм і правил (Лопатинська, 2015). Однак у наведених визначеннях простежується певна одностайність: мовленнєва компетенція - це уміння організувати процес спілкування 3 доцільним і доречним використанням мовних і позамовних засобів з урахуванням відповідної ситуації спілкування.

Отже, співвідношення понять мовна компетенція та мовленнєва компетенція відбувається за тим самим принципом, що й співвідношення мова мовлення: мова - це засіб, а мовлення - спосіб. Таким чином, формування мовленнєвої компетенції високого рівня неможливе без якісної базової мовної підготовки й вироблення відповідних умінь і навичок.

Розглянемо деякі форми роботи й різновиди завдань, які доцільно застосовувати на заняттях 3 української мови за професійним спрямуванням для формування мовної та мовленнєвої компетенцій, які складатимуть окремі загальні («Здатність до письмової та усної комунікації державною мовою», «Здатність працювати в команді», «Здатність до пошуку, оброблення та аналізу інформації $з$ різних джерел») й фахові («Здатність володіти фаховою термінологією державною мовою», «Здатність володіти основами наукових досліджень», «Здатність володіти методикою викладання образотворчого мистецтва й дизайну») компетентності, передбачені освітньо-професійними програмами (ОПП, 2017: 5-6), у здобувачів вищої освіти, що навчаються за спеціалізаціями «Графічний дизайн», «Мультимедійний дизайн», «Образотворче мистецтво», «Декоративне мистецтво», «Реставрація».

У Національній доктрині розвитку освіти визначено, що пріоритетом державної політики $\epsilon$ формування мовної особистості, людини самодостатньо комунікативно компетентної, здатної та готової до спілкування в будь-якій життєвій ситуації та в різних сферах суспільного життя (НДРОУ, 2003: 286), зокрема й у професійній діяльності. Відповідно до цього освітньо-професійна програма передбачає вироблення загальної компетентності «Здатність до письмової та усної комунікації державною мовою».

На нашу думку, зазначена компетентність складається з орфографічної, лексичної, граматичної, текстотвірної та стилістичної компетенцій як компонентів мовної компетенції. Розглянемо детальніше кожну 3 них.

Для формування орфографічної компетениї, яку витлумачуємо як уміння передавати слова на письмі відповідно до правил правопису, опти- 
Голтвеницька М. Компетентнісний піцхі^ у викмаданні української мови...

мально застосовувати всі різновиди вправ, які здобувачі вищої освіти традиційно виконували в основній школі. Систематизація знань 3 орфографії буде продуктивнішою, якщо викладач запроваджуватиме окремі прийоми технології критичного мислення (Тєлєжкіна, 2016: 209), що уможливить урізноманітнення форм роботи й пожвавить навчальний процес.

Лексичну компетениію розглядаємо як свідоме вмотивоване дотримання лексичних норм сучасної української літературної мови: вживання слів у властивому їм значенні, закріпленому в академічному тлумачному словнику; використання слів 3 урахуванням історичних процесів у лексиці й семантиці; вживання слів з урахуванням лексикосемантичних відношень між ними; врахування правил сполучуваності слів.

Під час вивчення навчального курсу «Українська мова (за професійним спрямуванням)» вироблення лексичної компетенції насамперед передбачає роботу 3 термінологічною лексикою, що сприятиме також формуванню однієї з фахових компетентностей «Здатність володіти фаховою термінологією державною мовою».

Для розвитку лексичної компетенції здобувачів вищої освіти доцільно застосовувати в навчальному процесі завдання такого типу:

1. З'ясуйте значення поданих слів (за необхідності звертайтеся до тлумачного словника). Визначте сферу їхнього використання.

Інсталяція, маркетинг, свідок, волонтер, декорація, викрутка, вакуум, коагуляція, меморандум, інфляція.

2. Згрупуйте запропоновані терміни за походженням: запозичені й власне українські.

Фронтон, балясина, ротонда, маскарон, прогін, кесон, тяга, вітраж.

3. Доберіть терміни на позначення пропонованих понять.

а) верхня частина опори (колони, пілястри), що міститься між опорою та антаблементом; б) архітектурний елемент над карнизом внутрішнього приміщення, є переходом від стіни до стелі;

в) прямокутний двір, площа, оточена 3 чотирьох сторін критою колонадою;

г) вид орнаменту із самостійних елементів, які передають мотиви зі сфери мистецтва, природи, життя;

д) один із видів скульптурного зображення на площині, всі частини якого виступають над площиною менш ніж на $1 / 2$ свого об'єму.

4. Скориставшись словником, поясніть значення багатозначних термінів за наведеним зразком. Складіть словосполучення.

\begin{tabular}{|l|l|l|}
\hline термін & \multicolumn{1}{|c|}{ галузь } & \multicolumn{1}{|c|}{ значення } \\
\hline \multirow{5}{*}{ знак } & лінгвістика & $\begin{array}{l}\text { письмове зображення звука чи } \\
\text { сполучення звуків мови: знак } \\
\text { м'якиення }\end{array}$ \\
\cline { 2 - 3 } & музика & $\begin{array}{l}\text { зображення 3 відомим умов- } \\
\text { ним значенням: нотний знак }\end{array}$ \\
\cline { 2 - 3 } & дизайн & $\begin{array}{l}\text { унікальний графічний елемент: } \\
\text { фірмовий знак }\end{array}$ \\
\hline
\end{tabular}

База, сепія, балка, гурт, карниз, абразія, сангіна.

5. Утворіть термінологічні словосполучення 3 наведених термінів, з'єднавши їх за зразком (рис. 1).

6. З'ясуйте значення поданих багатозначних термінів (за необхідності звертайтеся до тлумачного словника). 3 кожним із них складіть словосполучення, які б ілюстрували ваше пояснення виявлених лексичних значень.

Жирандоль, канелюри, кронштейн, пілон, фриз.

Граматичну компетенцію трактуємо як усвідомлене дотримання граматичних норм сучасної української літературної мови: системи відмінювання самостійних частин мови; правильного використання службових частин мови відповідно до значення утворюваних словосполучень і речень; прямого порядку слів у реченні; правил керування та узгодження.

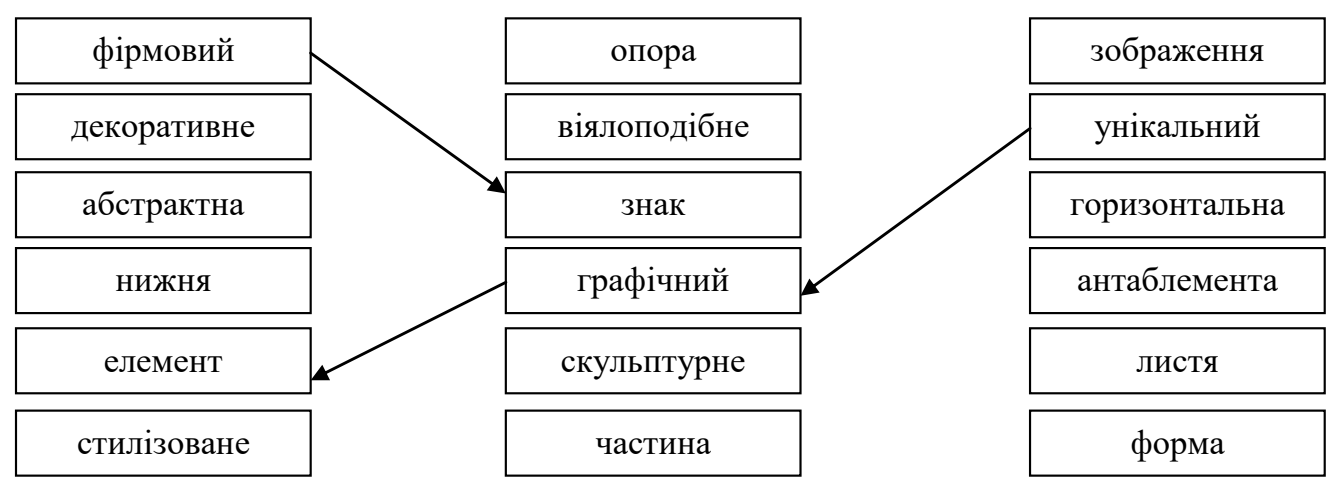

Рис. 1 
Наведемо зразки деяких завдань, виконання яких доречно запроваджувати на заняттях для формування граматичної компетенції:

1. Запишіть запропоновані терміни у формі родового відмінка однини. Згрупуйте у дві колонки: а) закінчення -а (-я); б) закінчення -у (-ю). Поясніть, чому наведені слова мають такі закінчення.

Дизайн, бізнес-процес, синтез, механізм, акант, альков, барельєф, гіпостиль, еркер, іоник, пристрій, функціоналізм, центр (композиціі), стайлінг, ритм, ланцюг.

2. Виправте помилки в наведених словосполученнях. Запишіть правильний варіант.

Навчати техніці різьблення, області дизайну, конкурсна комісія по розгляду..., сталося за помилкою, працювати по сумісництву, концептуальна задача, розповідали за практику, спіралевидний завиток, цей проєкт більш дорожчий попереднього.

3. Перекладіть словосполучення, дотримуючись правил лексичної сполучуваності й граматичного узгодження та керування. Запишіть їх.

a) Южная область Европы, Сумская область, область вечных снегов, область озер, область дизайна, новая область науки, боль в области сердца;

б) образование трещины, образование партии, получить хорошее образование.

4. Відновіть правильний порядок слів у запропонованих реченнях. Запишіть їх, розставляючи потрібні розділові знаки.

а) крок каркас створення який собою дизайну суто без будь-якого макету являє інформаційний;

б) у навігацію макеті намічає первинну та функціональні та деякі вторинну зміст можливості розробник.

Текстотвірна й стилістична компетенціі взаємопов'язані, оскільки текстотворення передбачає оперування засобами того чи того стилю. Окрім того, формування текстотвірної компетенції неможливе без реалізації орфографічної, лексичної та граматичної компетенцій.

Для вироблення умінь і навичок сприймати чужий текст і створювати власний доцільно виконувати вправи лексико-семантичного, логіко-структурного, аналітичного й продуктивного характеру.

Завдання логіко-структурного різновиду можуть бути такими:

1. Прочитайте подані речення. Відновіть їх правильну послідовність у запропонованому уривку.

Окрім цього, з'явилась можливість зводити багатоповерхові будинки й павільйони. Вперше метал почав використовуватися в будівництві будівель і мостів. Розвитку західноєвропейської архітектури кінця XIX - початку XX ст. сприяли досягнення металургійної промисловості й виникнення нових будівельних матеріалів. Така конструкція давала можливість використовувати велику кількість скла, що надавало спорудам легкості й повітряності. На творчість архітекторів суттєво вплинули можливості металу.

2. Прочитайте запропонований текст. Визначте тип мовлення та стильову належність тексту. Відповідь аргументуйте.

Сучасна техніка самобутнього петриківського розпису виникла в XVII ст. разом із приходом у Петриківку, що на Дніпропетровщині, перших поселенців. Відтоді петриківський розпис став невіддільною частиною українського побуту. Люди, будуючи світлі хати-мазанки, розписували ïx пишними квітковими малюнками, створюючи цілий художній ансамбль, адже прикрашали не лише інтер'єр будинку (стіни, піч), але й зовнішній фасад, а ще посуд, весільні скрині, меблі й інше хатнє начиння.

Господарів, чиї оселі не були розписані яскравими орнаментами, в селі не поважали, вважаючи їх морально убогими й не гідними навіть вітань односельців.

Петриківський розпис - це своєрідний декоративно-художній літопис флори й фауни Придніпров'я. Як майстерно селищні художники передають динаміку пташиного польоту, як тонко відтворюють найменші коливання рослин від вітру, як вишукано поєднують світло й тіні! (3 журналу).

Для продуктивної творчої діяльності студентам необхідно пропонувати для виконання завдання описати чи схарактеризувати якесь мистецьке явище, наприклад:

1. Опишіть картину С. Васильківського «Сторожа козацьких вольностей» (1890р.) у художньому (епічний підстиль) i науковому (науково-навчальний підстиль) стилях. Порівняйте отриманий результат.

2. Опишіть картину А. Горської «Портрет батька» (1960р.) у публіцистичному (власне публіцистичний підстиль) й науковому (власне науковий підстиль) стилях. Порівняйте отриманий результат.

3. Опишіть картину I. Труша «Трембітарі» в науковому стилі (науково-навчальний і науковопопулярний підстилі).

Загальна компетентність «Здатність працювати в команді» також може бути сформована на заняттях $з$ української мови за професійним спрямуванням. I реалізувати це завдання можна 
завдяки використанню проєктної технології під час вивчення окремих тем, зокрема «Паронімія в термінології, якою послуговується дизайнер». Проєктне навчання допоможе сформувати в студентів якості, необхідні їм для подальшого навчання, соціальної та професійної адаптації та відповідно - професійної діяльності (Тєлєжкіна, 2014: 142).

Формуванню загальної компетентності «Здатність до пошуку, оброблення та аналізу інформації 3 різних джерел» і фахової компетентності «Здатність володіти основами наукових досліджень» сприятиме застосування вправ репродуктивного й продуктивного характеру, наприклад:

1. Уважно прочитайте пропонований текст. Поетапно складіть і запишіть різні види планів (питальний, називний (простий, складний), цитатний, тезовий) до тексту: Антонович $€$. А., Вдовченко В. В. «Фундаментальні та прикладні дослідження синтезу дизайну і технологій у системі неперервної дизайнерської та технологічної освіти» (Становлення і розвиток етнодизайну: украӥнський та європейський досвід : збірник наукових праць. Полтава : Полтавський літератор, 2012. Кн. 1. C. 104-113).

2. Ознайомившись із наведеною статтею, складіть тези прочитаного.

3. Прокоментуйте наведене висловлювання.

У голові в нього був справжній вінегрет, i такий самий вигляд мало те, чим він нас приголомшував. Спочатку він подав морозиво, а після нього - суп. Наступними стравами виявилися риба й горіхи (Д. Карнегі).

Вироблення фахової компетентності «Здатність володіти методикою викладання образотворчого мистецтва й дизайну» неможливе без набуття умінь 3 академічної риторики. Для цього необхідно застосовувати завдання такого плану:
1. На семінарі $з$ дисципліни «Організація праці дизайнера» Ви отримали завдання: підготувати доповідь на тему «Організація робочого простору». Складіть вступ і висновки до цієї промови.

2. Ознайомтеся 3 пропонованим уривком. Доповніть наведений текст так, щоб у вас склалася смислово завершена промова. Підготуйтеся до іiї виголошення перед аудиторією.

Нова течія в архітектурі допускала творення в конкретному природному оточенні $з$ урахуванням місцевих звичаїв. Програмним принципом постмодернізму стала стильова еклектика: цитати з різних стилів та епох, їх творче перероблення, подекуди жартівливе й гротескове.

Увесь період, починаючи 3 кінця 1960-х pp. i дотепер, можна вважати постмодерністським (Iз підручника).

Уважаємо, що наведені зразки практичних завдань 3 української мови сприятимуть формуванню мовної та мовленнєвої компетенцій, що входять до складу виокремлених фахових і загальних компетентностей здобувачів вищої освіти.

Висновки. Викладене дозволяє зробити висновки про те, що застосування компетентнісного підходу уможливлює узгодження мети навчання, визначеної педагогами, $з$ метою самих студентів. У зв'язку із цим головним учасником освітнього процесу стає саме студент, який розвиває особистісний потенціал, завдяки чому підвищується рівень мотивованості для самостійного досягнення поставленої мети, розвивається уміння самостійно приймати важливі рішення.

Перспективу розвідки вбачаємо в дослідженні можливостей застосування сучасних інноваційних технологій навчання на заняттях з української мови за професійним спрямуванням для вироблення комунікативної компетентності здобувачів вищої освіти творчих спеціальностей.

\section{СПИСОК ВИКОРИСТАНИХ ДЖЕРЕЛ}

1. Бібік Н. М. Компетентнісний підхід: рефлексивний аналіз застосування. Компетентнісний підхід в освіті: світовий досвід та українські перспективи. Бібліотека освітньої політики. Київ : К.І.С., 2004. С. 47-52.

2. Глазова О. П. Словесник - творець Ноmo eloguens. URL: http://ippo.org.ua (дата звернення: 10.01.2021).

3. Срмаков I. Г., Пузіков Д. О. Структура життєвої компетентності: життєтворчі компетенції особистості. Компетентнісно спрямована освіта: перший досвід, порівняльні підходи, перспективи. Київ : КІСП, 2011. С. 20-25.

4. Заболоцька Л. А. Педагогічні умови формування комунікативних умінь учителя. Науковий вісник Мелітопольського державного педагогічного університету. Серія «Педагогіка». 2003. C. 87-92. URL: http://lib.mdpu.org.ua/nvsp/ BAK7/7/14.pdf (дата звернення: 20.01.2021).

5. Кордонська А. В. Формування мовленнєвої компетенції студентів на заняттях української мови за професійним спрямуванням. 2018. URL: http://intkonf.org/kordonska-av-formuvannya-movlennevoyi-kompetentsiyi-studentiv-nazanyattyah-ukrayinskoyi-movi-za-profesiynim-spryamuvannyam/ (дата звернення: 10.01.2021).

6. Крутій К. Л. Формування ключових компетенцій у дітей дошкільного віку в умовах полілінгвальності. Конспекти занять із навчання української мови і розвитку мовлення дітей середнього дошкільного віку : методичний посібник / К. Л. Крутій, Н. І. Котій та ін. Запоріжжя : ТОВ «ЛІПС» ЛТД, 2007. 248 с.

7. Лопатинська Н. А. Мовна, мовленнєва та комунікативна компетенції у студентів вищих навчальних закладів як складники фахової культури майбутнього корекційного педагога. Актуальні питання корекційної освіти (педагогічні науки) : Збірник наукових праць. 2015. Випуск 5. С. 187-197. URL: http://aqce.com.ua/vipusk-n5-2014/lopatinska-na- 
movna-movlennjeva-ta-komunikativna-kompetencii-u-studentiv-vicshih-navchalnih-zakladiv-jak-skladniki-fahovoi-kulturimajbutnogo-korekcijnogo-pedagoga.html (дата звернення: 15.01.2021).

8. Мамчур Л. І. Мовна і комунікативна компетентність особистості: суть і характерні ознаки. Педагогічні науки : збірник наукових праць. Херсон : Видавництво ХДПУ, 2006. Вип 42. С. 193-197. URL: https://ps.journal.kspu.edu/ index.php/ps/article/view/916/818 (дата звернення: 10.01.2021).

9. Національна доктрина розвитку освіти України у XXI ст. Науково-освітній потенціал нації: погляд у XXI століття. Київ : Навчальна книга, 2003. 943 с.

10. Освітньо-професійна програма «Дизайн (за видами)» першого рівня вищої освіти за спеціальністю 022 «Дизайн» (спеціалізації «Графічний дизайн», «Мультимедійний дизайн»); галузь знань 02 «Культура і мистецтво»; кваліфікація: бакалавр дизайну / Керівник проєктної групи О. В. Ганоцька. Харків, 2017. 14 с.

11. Освітньо-професійна програма «Образотворче мистецтво, декоративне мистецтво, реставрація» першого рівня вищої освіти за спеціальністю 023 «Образотворче мистецтво, декоративне мистецтво, реставрація»; галузь знань 02 «Культура і мистецтво»; кваліфікація: бакалавр образотворчого мистецтва, декоративного мистецтва, реставрації / Керівник проєктної групи Л. П. Горбатенко. Харків, 2017. 15 с.

12. Островська Л. С., Беганська І. Ю. Особливості формування мовної компетенції студентів економічних ВНЗ Донеччини. Донецький вісник наукового товариства ім. Т. Г. Шевченка. 2009. Т. 26. С. 141-150. URL: http://litmisto. org.ua/?p=19950 (дата звернення: 19.01.2021).

13. Стёпина С. Н. Компетентностный поход в обучении информатики. Молодой учёный. Чита : Молодой учёный, 2009. C. 192-197.

14. Тєлєжкіна О. О. Застосування методів технології розвитку критичного мислення у викладанні фахової української мови. Стратегї̈ міжкультурної комунікації в мовній освіті сучасного ВНЗ. Київ : КНЕУ, 2016. С. 207-210.

15. Тєлєжкіна О. О. Застосування проєктної технології на заняттях з української мови (за професійним спрямуванням) у вищих навчальних закладах. Нова педагогічна думка. Рівне, 2014. № 2 (78). С. 141-144.

16. Хомский Н. Язык и мышление / Перевод с английского Б. Ю. Городецкого. Москва : Изд-во МГУ, 1972.123 с.

17. Шумарова А. Н. Мовна компетенція особистості в ситуації білінгвізму. Київ : Вид-во КДЛУ, 2000. 283 с.

\section{REFERENCES}

1. Bibik N. M. Kompetentnisnyi pidkhid: refleksyvnyi analiz zastosuvannia [Competence approach: reflexive analysis of application]. Kompetentnisnyi pidkhid v osviti: svitovyi dosvid ta ukrainski perspektyvy. Biblioteka osvitnoi polityky. Kyiv: K.I.S., 2004. pp. 47-52 [in Ukrainian].

2. Hlazova O. Slovesnyk - tvorets Homo eloguens [The linguist is the creator Homo eloguens]. [Elektronnyi resurs]. URL: http://ippo.org.ua (data zvernennia: 10.01.2021) [in Ukrainian].

3. Yermakov I. H., Puzikov D. O. Struktura zhyttievoi kompetentnosti: zhyttietvorchi kompetentsii osobystosti [The structure of life competence: life-creating competencies of the individual]. Kompetentnisno spriamovana osvita: pershyi dosvid, porivnialni pidkhody, perspektyvy. Kyiv: KISP, 2011. pp. 20-25 [in Ukrainian].

4. Zabolotska L. A. Pedahohichni umovy formuvannia komunikatyvnykh umin uchytelia [Pedagogical conditions of formation of communicative skills of the teacher]. [Elektronnyi resurs]. URL: http://lib.mdpu.org.ua (data zvernennia: 20.01.2021).

5. Kordonska A. V. Formuvannia movlennievoi kompetentsii studentiv na zaniattiakh ukrainskoi movy za profesiinym spriamuvanniam [Formation of speech competence of students in Ukrainian language classes in a professional direction]. [Elektronnyi resurs]. URL: http://intkonf.org (data zvernennia: 10.01.2021).

6. Krutii K. L. Formuvannia kliuchovykh kompetentsii u ditei doshkilnoho viku v umovakh polilingvalnosti [Formation of key competencies in preschool children in the conditions of polylingualism]. [Elektronnyi resurs]. URL: http://www. ukrdeti.com (data zvernennia :19.01.2021).

7. Lopatynska N. A. Movna, movlennieva ta komunikatyvna kompetentsii u studentiv vyshchykh navchalnykh zakladiv yak skladnyky fakhovoi kultury maibutnoho korektsiinoho pedahoha [Language, speech and communicative competencies of students of higher educational institutions as components of the professional culture of the future correctional teacher]. [Elektronnyi resurs]. URL: http://aqce.com.ua (data zvernennia: 15.01.2021).

8. Mamchur L. I. Movna i komunikatyvna kompetentnist osobystosti: sut i kharakterni oznaky [Linguistic and communicative competence of the individual: the essence and characteristics]. [Elektronnyi resurs]. URL: http:// ps.stateuniversity.ks.ua (data zvernennia: 10.01.2021).

9. Natsionalna doktryna rozvytku osvity Ukrainy u XXI st. [National doctrine of education development of Ukraine in the XXI century]. Naukovo-osvitnii potentsial natsii: pohliad u XXI stolittia. Kyiv: Navchalna knyha, 2003. 943 s. [in Ukrainian].

10. Osvitno-profesiina prohrama "Dyzain (za vydamy)" pershoho rivnia vyshchoi osvity za spetsialnistiu 022 "Dyzain" (spetsializatsii "Hrafichnyi dyzain", "Multymediinyi dyzain"); haluz znan 02 "Kultura i mystetstvo"; kvalifikatsiia: bakalavr dyzainu [Educational and professional program "Design (by type)" of the first level of higher education in the specialty 022 "Design" (specializations "Graphic Design", "Multimedia Design"); field of knowledge 02 "Culture and Art"; qualification: bachelor of design]. Kerivnyk proektnoi hrupy O. V. Hanotska. Kharkiv: [b. v.], 2017. 14 s. [in Ukrainian].

11. Osvitno-profesiina prohrama "Obrazotvorche mystetstvo, dekoratyvne mystetstvo, restavratsiia" pershoho rivnia vyshchoi osvity za spetsialnistiu 023 "Obrazotvorche mystetstvo, dekoratyvne mystetstvo, restavratsiia"; haluz znan 02 "Kultura i mystetstvo"; kvalifikatsiia: bakalavr obrazotvorchoho mystetstva, dekoratyvnoho mystetstva, restavratsii [Educational and professional program "Fine Arts, Decorative Arts, Restoration" of the first level of higher education in the specialty 023 "Fine Arts, Decorative Arts, Restoration"; field of knowledge 02 "Culture and Art"; qualification: bachelor of fine arts, decorative arts, restoration]. Kerivnyk proektnoi hrupy L. P. Horbatenko. Kharkiv: [b. v.], 2017. 15 s. [in Ukrainian]. 
Голтвеницька М. Компетентнісний пімхі^ у викмаханні української мови...

12. Ostrovska L., Behanska I. Osoblyvosti formuvannia movnoi kompetentsii studentiv ekonomichnykh VNZ Donechchyny [Features of formation of language competence of students of economic universities of Donetsk region]. [Elektronnyi resurs]. URL: http://litmisto.org.ua (data zvernennia: 19.01.2021).

13. Styopina S. N. Kompetentnostnyiy pohod v obuchenii informatiki [Competence approach in teaching computer science]. Molodoy uchYonyiy. Chita: Molodoy uchYonyiy 2009. pp. 192-197 [in Russia].

14. Tieliezhkina O. O. Zastosuvannia metodiv tekhnolohii rozvytku krytychnoho myslennia u vykladanni fakhovoi ukrainskoi movy [Application of methods of technology of development of critical thinking in teaching of professional Ukrainian language]. Stratehii mizhkulturnoi komunikatsii v movnii osviti suchasnoho VNZ. Kyiv: KNEU, 2016. pp. $207-210$. [in Ukrainian].

15. Tieliezhkina O. O. Zastosuvannia proektnoi tekhnolohii na zaniattiakh z ukrainskoi movy (za profesiinym spriamuvanniam) u vyshchykh navchalnykh zakladakh [Application of project technology in Ukrainian language classes (for professional purposes) in higher educational institutions]. Nova pedahohichna dumka. Rivne 2014. № 2 (78). pp. 141-144 [in Ukrainian].

16. Homskiy N. Yazyik i myishlenie [Language and thinking]. Perevod s angliyskogo B. Yu. Gorodetskogo. Moskva: Izd-vo MGU, 1972. 123 s. [in Russia].

17. Shumarova A. N. Movna kompetentsiia osobystosti v sytuatsii bilinhvizmu [Linguistic competence of an individual in a situation of bilingualism]. Kyiv: Vyd-vo KDLU, 2000. 283 s. [in Ukrainian]. 